\title{
Spatial-temporal dynamics and recovery mechanisms of dried soil layers under Robinia pseudoacacia forest based on in-situ field data from 2017-2020
}

\author{
Meina $\mathrm{He}^{1}$, Yunqiang Wang ${ }^{2}$, Li Wang ${ }^{1}$, Xiaoxu Jia ${ }^{3}$, Chunlei Zhao ${ }^{1}$, and Ping Zhang ${ }^{1}$ \\ ${ }^{1}$ Northwest Agriculture and Forestry University \\ ${ }^{2}$ Chinese Academy of Sciences \\ ${ }^{3}$ Institute of Geographic Sciences and Natural Resources Research Chinese Academy of \\ Sciences
}

February 16, 2022

\begin{abstract}
Planting Robinia pseudoacacia in water-limited regions can promote soil and water conservation and improve ecological service function. However, it can also cause the formation of below-ground dried soil layers (DSLs), causing land degradation and tree mortality. To ascertain the spatial-temporal dynamics and recovery processes of DSLs, we monitored the deep soil water content (SWC) to a depth of $500 \mathrm{~cm}$ at 27 sites on a typical R. pseudoacacia forest (planted in 2003) hillslope from 2017-2020, and calculated the evaluation indices of DSLs based on plant and soil criteria. We found that, compared to plant criterion identified-DSLs, the degree of soil criterion identified-DSLs was more severe, although the spatial-temporal characteristics were similar. Severe soil desiccation was identified in the forest as $79 \%$ of the $500 \mathrm{~cm}$ profile drying out below $101 \mathrm{~cm}$. During the study period, the mean thickness of DSLs and mean SWC within DSLs were $397 \mathrm{~cm}$ and 9.0\%, respectively, and the quantitative index of DSLs reached level III ( $>0.51$, severe DSLs). All DSL indices demonstrated weak or moderate variability in space and strong variability in time. Interestingly, two rainfall events triggered DSL disappearance at seven sites, indicating the possibility of DSL recovery under heavy rainfall. Possible mechanisms explaining the DSLs recovery phenomenon were linked with continued rainfall, micro-topography, soil texture, individual root characteristics, and their interactions. This information is helpful for soil water management and land development in planted forests and for reclaiming DSLs under similar conditions.
\end{abstract}

\section{Hosted file}

Manuscript.docx available at https://authorea.com/users/460764/articles/556633-spatialtemporal-dynamics-and-recovery-mechanisms-of-dried-soil-layers-under-robiniapseudoacacia-forest-based-on-in-situ-field-data-from-2017-2020

\section{Hosted file}

Figures.pdf available at https://authorea.com/users/460764/articles/556633-spatial-temporaldynamics-and-recovery-mechanisms-of-dried-soil-layers-under-robinia-pseudoacacia-forestbased-on-in-situ-field-data-from-2017-2020

\section{Hosted file}

Tables.docx available at https://authorea.com/users/460764/articles/556633-spatial-temporaldynamics-and-recovery-mechanisms-of-dried-soil-layers-under-robinia-pseudoacacia-forestbased-on-in-situ-field-data-from-2017-2020 


\section{Hosted file}

Highlights.docx available at https://authorea.com/users/460764/articles/556633-spatialtemporal-dynamics-and-recovery-mechanisms-of-dried-soil-layers-under-robiniapseudoacacia-forest-based-on-in-situ-field-data-from-2017-2020

\section{Hosted file}

Cover letter.docx available at https://authorea.com/users/460764/articles/556633spatial-temporal-dynamics-and-recovery-mechanisms-of-dried-soil-layers-under-robiniapseudoacacia-forest-based-on-in-situ-field-data-from-2017-2020 